\title{
Potensi Daya Tarik Wisata Grhatama Pustaka Yogyakarta Sebagai Wahana Rekreasi
}

\author{
Eko Sugiarto, Sabda Elisa Priyanto \\ Sekolah Tinggi Pariwisata Ambarrukmo Yogyakarta \\ ekostipram@gmail.com, sabda.priyanto@gmail.com
}

\begin{abstract}
This research is a descriptive study, looking for the potential attractions of Grhatama Pustaka Yogyakarta as a recreation place based on the perspective of visitors. Primary data were collected by interview and observation methods. This primary data is then supplemented with secondary data obtained from a variety of relevant literature. The results of this study are the potential of the tourist attraction of Grhatama Pustaka Yogyakarta as a place of recreation based on the perspective of the visitors in uniqueness, which cannot be found anywhere else. The conclusion of this research is Grhatama Pustaka Yogyakarta is interesting to visit because it is unique so it has the potential to become a tourist attraction. However, at this time the function of Grhatama Pustaka Yogyakarta is still not yet optimal as a recreation place. Therefore, further studies are still needed on developing the tourism potential of Grhatama Pustaka Yogyakarta so that its function as a recreation place can be better.
\end{abstract}

Keywords : Potential; Tourist Attraction; Perspective; Visitors

\begin{abstract}
Abstrak
Penelitian ini merupakan penelitian deskriptif yang bertujuan mengetahui potensi daya tarik wisata Grhatama Pustaka Yogyakarta sebagai wahana rekreasi berdasarkan perspektif pemustaka. Data primer dikumpulkan dengan metode wawancara dan observasi. Data primer ini kemudian diperkaya dengan data sekunder yang diperoleh dari berbagai literatur yang relevan. Hasil penelitian ini menunjukkan bahwa potensi daya tarik wisata Grhatama Pustaka Yogyakarta sebagai wahana rekreasi berdasarkan perspektif pemustaka terletak pada unsur keunikan, yaitu sesuatu yang sulit ditemukan kesamaannya atau bahkan tidak ditemukan di perpustakaan lain. Simpulan penelitian ini adalah berdasarkan perspektif pemustaka, Grhatama Pustaka Yogyakarta menarik untuk dikunjungi karena memiliki keunikan sehingga berpotensi menjadi daya tarik wisata. Meskipun demikian, saat ini fungsi Grhatama Pustaka Yogyakarta sebagai wahana rekreasi belum maksimal. Oleh karena itu, diperlukan kajian lebih lanjut tentang pengembangan
\end{abstract}


potensi daya tarik wisata Grhatama Pustaka Yogyakarta agar fungsinya sebagai wahana rekreasi bisa lebih maksimal.

Kata Kunci : Potensi; Daya Tarik Wisata; Perspektif; Pemustaka

\section{A. PENDAHULUAN}

Perpustakaan mempunyai beberapa fungsi. Pasal 3 Undang-Undang Nomor 43 Tahun 2007 tentang Perpustakaan menyebutkan bahwa perpustakaan berfungsi sebagai wahana pendidikan, penelitian, pelestarian, informasi, dan rekreasi untuk meningkatkan kecerdaskan dan keberdayaan bangsa. Pasal ini secara jelas menyebutkan bahwa salah satu fungsi perpustakaan adalah sebagai wahana rekreasi.

Grhatama Pustaka adalah perpustakaan yang cukup dikenal di Daerah Istimewa Yogyakarta. Perpustakaan ini memiliki koleksi buku bacaan yang lengkap, terdiri atas 250.000 eksemplar buku dari total 180.000 judul buku, berupa buku fiksi maupun non fiksi baik dalam format cetak maupun digital serta koleksi langka dan berbagai naskah kuno yang diperoleh dari perpustakaan Kraton dan Puro Pakualaman yang telah mengalami proses digitalisasi (Sekarini, 2016). Koleksi yang relatif lengkap di Grhatama Pustaka menjadikan perpustakaan ini sebagai salah satu ikon yang cukup bisa dibanggakan oleh warga Yogyakarta.

Sebagai salah satu kebanggaan masyarakat Yogyakarta, selain semakin mengukuhkan predikat Yogyakarta sebagai "Kota Pelajar", Grhatama Pustaka semestinya juga semakin mengukuhkan Yogyakarta sebagai salah satu daerah tujuan wisata. Dalam konteks ini sudah semestinya fungsi Grhatama Pustaka sebagai wahana rekreasi mendapat perhatian dari semua pihak. Jika selama ini kegiatan rekreasi selalu diidentikkan dengan pantai, gunung, hutan, dan berbagai bentuk fenomena alam yang ada di Yogyakarta, sudah saatnya berbagai pihak terkait mendorong masyarakat agar mereka menjadikan perpustakaan khususnya Grhatama Pustaka sebagai tujuan rekreasi. Terkait hal ini, peneliti tertarik untuk mengetahui apa saja potensi daya tarik Grhatama Pustaka sebagai wahana rekreasi berdasarkan perspektif pemustaka.

Penelitian tentang Grhatama Pustaka sudah pernah dilakukan oleh peneliti terdahulu. Meskipun demikian, penelitian yang secara spesifik membahas tentang potensi daya tarik Grhatama Pustaka sebagai wahana rekreasi berdasarkan perspektif pemustaka belum pernah dilakukan oleh peneliti terdahulu. Berikut beberapa penelitian tentang Grhatama Pustaka yang pernah dilakukan. 
Mianto meneliti tentang persepsi pemustaka terhadap kualitas pelayanan sirkulasi di Badan Perpustakaan dan Arsip Daerah (BPAD) Daerah Istimewa Yogyakarta. Hasil penelitian Mianto menyebutkan bahwa kualitas pelayanan sirkulasi di BPAD DIY tergolong baik (Mianto, 2014). Meskipun demikian, beberapa kualitas pelayanan yang ada di perpustakaan ini masih perlu ditingkatkan. Beberapa hal yang perlu ditingkatkan adalah penyusunan rak koleksi yang harus sesuai subjek klasifikasi, penambahan koleksi terbitan baru yang sesuai kebutuhan pemustaka, dan pemberian pelayanan yang tidak boleh membeda-bedakan antara satu pemustaka dengan pemustaka lain.

Puspitasari meneliti tentang peranan Badan Perpustakaan dan Arsip Daerah Provinsi Daerah Istimewa Yogyakarta dalam pengelolaan arsip daerah untuk meningkatkan pelayanan arsip terhadap publik. Hasil penelitian Puspitasari menunjukkan bahwa peranan BPAD DIY sudah sesuai dengan pedoman pelaksanaan kearsipan yang ada. Untuk meningkatkan pelayanan arsip terhadap publik, BPAD DIY membuka beberapa layanan arsip. Layanan arsip ini berupa layanan langsung maupun layanan tidak langsung. Selain itu, perpustakaan ini mengadakan pameran arsip sebagai sebuah bentuk layanan yang lain. (Puspitasari, 2015)

Musrifah meneliti tentang proteksi arsip vital pada Badan Perpustakaan dan Arsip Daerah di Yogyakarta. Dalam laporan hasil penelitiannya, Musrifah menyimpulkan bahwa proteksi terhadap arsip vital yang dilakukan oleh BPAD DIY lebih mengutamakan fisik dari arsip vital itu sendiri agar tetap tersimpan secara utuh dan selamat dari berbagai bencana. Arsip vital disimpan di setiap unit kerja yang selalu memanfaatkan arsip tersebut. (Musrifah, 2016)

Aisyah (2017) meneliti tentang implementasi kebijakan aksesibilitas pelayanan bagi difabel di Yogyakarta tahun 2015 dengan studi kasus Grhatama Pustaka Yogyakarta. Hasil penelitian Aisyah menyebutkan bahwa kebijakan akesibilitas pelayanan Grhatama Pustaka bagi difabel tahun 2015 belum baik karena beberapa aksesibilitas yang dibutuhkan difabel belum sepenuhnya tersedia di perpustakaan Grhatama Pustaka. Selain itu, aksesibilitas pelayanan yang diberikan oleh Grhatama Pustaka belum memudahkan difabel untuk melakukan aktivitas di dalam perpustakaan. Pihak pemerintah khususnya perpustakaan Grhatama Pustaka juga diharapkan untuk melakukan audit atau perbaikan aksesibilitas pelayanan terkhusus untuk difabel serta melakukan diskusi dengan perwakilan pemustaka normal dan difabel (perwakilan tunanetra, tunadaksa, dan lainlain). (Aisyah, 2017) 
Penelitian-penelitian yang sudah pernah dilakukan sebagaimana dipaparkan di atas menunjukkan bahwa penelitian tentang potensi daya tarik Grhatama Pustaka sebagai wahana rekreasi berdasarkan perspektif pemustaka belum pernah dilakukan oleh peneliti terdahulu. Oleh karena itu, peneliti mengangkat tema ini untuk melengkapi penelitian-penelitian sebelumnya.

Penelitian ini merupakan penelitian deskriptif (descriptive research). Penelitian deskriptif adalah penelitian yang bertujuan membuat deskripsi, gambaran atau lukisan secara sistematis, faktual, dan akurat mengenai faktafakta, sifat-sifat, serta hubungan antarfenomena yang diselidiki (Rukajat, 2018). Tujuan penelitian ini adalah untuk mengetahui potensi daya tarik wisata Grhatama Pustaka Yogyakarta sebagai wahana rekreasi berdasarkan perspektif pemustaka.

Data primer penelitian ini dikumpulkan dengan menggunakan dua teknik, yaitu wawancara dan observasi. Wawancara adalah cara mengumpulkan data dengan mengajukan pertanyaan kepada informan baik secara langsung melalui tatap muka maupun dengan bantuan alat komunikasi tertentu, misalnya telepon dan internet. Dalam penelitian ini wawancara dilakukan secara langsung kepada pemustaka di Grhatama Pustaka Yogyakarta. Observasi adalah cara mengumpulkan data dengan melakukan pengamatan langsung terhadap ruang, tempat, pelaku, kegiatan, waktu, peristiwa, tujuan, dan perasaan. Dalam penelitian ini, selain melakukan wawancara personal dengan pemustaka, peneliti melakukan pengamatan langsung di Grhatama Pustaka Yogyakarta. Baik teknik wawancara maupun observasi dalam praktik di lapangan dilakukan secara sekaligus karena keduanya akan saling melengkapi (Mamik, 2015).

Data sekunder penelitian ini diperoleh dengan teknik pengumpulan data dokumentasi. Teknik ini dilakukan dengan cara mengumpulkan dokumen-dokumen, baik berupa dokumen publik seperti koran, makalah, laporan kantor, maupun dokumen privat seperti buku harian, surat, surat elektronik, dan lain-lain (Creswell, 2012). Dalam penelitian ini, data sekunder diperoleh dari studi pustaka terhadap berbagai sumber tertulis terkait dengan Grhatama Pustaka Yogyakarta. Data sekunder digunakan untuk melengkapi dan memperkaya data primer yang sudah terkumpul.

Ketika data yang terkumpul dianggap cukup, kemudian dilakukan analisis data, yaitu proses mencari dan menyusun secara sistematis data yang diperoleh dari hasil wawancara, catatan lapangan, dan bahan-bahan lain sehingga mudah dipahami dan dapat diinformasikan kepada orang lain. (Sugiyono, 2013). 
Setelah semua data dianalisis, langkah selanjutnya adalah menyimpulkan hasil penelitian berdasarkan pada hasil analisis yang sudah dilakukan.

\section{B. HASIL DAN PEMBAHASAN}

\section{Batasan Istilah}

Sebelum membahas tentang potensi daya tarik wisata Grhatama Pustaka sebagai wahana rekreasi berdasarkan perspektif pemustaka, terlebih dahulu akan dijelaskan beberapa batasan istilah yang digunakan dalam tulisan ini. Sesuai dengan kata kunci, jumlah istilah ini ada empat, yaitu potensi, daya tarik wisata, perspektif, dan pemustaka.

Salah satu definisi potensi yang sangat umum adalah kemampuan yang mempunyai kemungkinan untuk dikembangkan .Dalam hal ini, ada "sesuatu" yang memungkinkan untuk dikembangkan. Istilah potensi yang muncul dalam tulisan ini mengacu kepada definisi ini. (Bahasa, 2016).

Daya tarik wisata adalah segala sesuatu baik berupa ciptaan Tuhan maupun hasil karya manusia yang memiliki keunikan, keindahan, dan makna tertentu sehingga menarik minat orang untuk berkunjung dan menikmati keberadaannya. (Sugiarto, 2016)

Berdasarkan pengertian ini, sesuatu bisa disebut sebagai daya tarik wisata jika memiliki kriteria keunikan, keindahan, dan makna. Keunikan berarti sesuatu yang sulit ditemukan kesamaannya atau bahkan tidak ditemukan di tempat lain (langka). Keindahan adalah sesuatu yang apabila dilihat atau didengar akan menimbulkan perasaan senang, terpukau, atau kagum sehingga timbul rasa puas secara emosional, bahkan secara spiritual. Sementara makna dikaitkan dengan aspek intangible ("takbenda", tak dapat diraba) yang melekat pada objek/sesuatu, misal terkait dengan (a) konsep mengenai sesuatu; (b) perlambangan yang diwujudkan melalui sesuatu; (c) fungsi atau kegunaan sesuatu; (d) isi pesan yang terkandung dalam sesuatu; (e) teknologi pembuatan; serta (f) pola tingkah laku yang terkait dengan pemanfaatan sesuatu.

Padanan "perspektif" adalah "sudut pandang" (Tim Penyusun Kamus Pusat Bahasa, 2016). Secara singkat perspektif dapat didefinisikan sebagai sebuah sudut pandang atau cara pandang seseorang atau kelompok tertentu tentang sesuatu. (Romrome, 2015) Dengan demikian, perspektif dalam tulisan ini mengacu kepada sudut pandang orang-orang yang berkunjung ke Grhatama Pustaka.

Pemustaka adalah pengguna perpustakaan, yaitu perseorangan, kelompok orang, masyarakat, atau lembaga yang memanfaatkan fasilitas 
layanan perpustakaan (Sekretariat Negara RI, 2007). Dalam tulisan ini, pemustaka mengacu kepada orang-orang yang datang berkunjung ke Grhatama Pustaka. Mereka bisa jadi terdaftar sebagai anggota Grhatama Pustaka (dibuktikan dengan kepemilikan kartu anggota), maupun yang tidak terdaftar sebagai anggota Grhatama Pustaka

\section{Gambaran Umum Informan}

Tujuan penelitian ini adalah mengetahui potensi daya tarik wisata Grhatama Pustaka Yogyakarta sebagai wahana rekreasi berdasarkan perspektif pemustaka. Karena yang dijadikan dasar adalah "perspektif pemustaka", dalam penelitian ini pemustaka adalah sumber data utama (data primer). Pemustaka mengacu kepada orang-orang yang datang berkunjung ke Grhatama Pustaka. Mereka bisa jadi terdaftar sebagai anggota Grhatama Pustaka (dibuktikan dengan kepemilikan kartu anggota), maupun yang tidak terdaftar sebagai anggota Grhatama Pustaka. Data primer dari pemustaka ini dikumpulkan dengan metode wawancara. Ketika melakukan wawancara, peneliti sekaligus melakukan pengamatan (observasi) di lokasi penelitian.

Pengumpulan data dalam penelitian ini dilakukan selama tujuh hari berturut-turut sejak hari Senin hingga hari Minggu agar diperoleh gambaran kondisi di lokasi penelitian dari hari ke hari dalam satu minggu. Setiap hari dilakukan wawancara secara acak kepada pemustaka selama tiga kali, yaitu pagi (pukul 08.00--12.00), siang (pukul 12.01--17.00), dan malam (18.00-tutup) agar diperoleh gambaran kondisi di lokasi penelitian dalam satu hari. Selama tujuh hari pengumpulan data, informan yang berhasil diwawancarai sebanyak 118 pemustaka. Meskipun demikian, hanya sebagian data yang ditampilkan dalam tulisan ini.

Fokus tulisan ini adalah data yang bersumber dari pemustaka yang berkunjung ke Grhatama Pustaka dengan tujuan utama untuk penyegaran (refreshing). Setelah dilakukan seleksi terhadap 118 kelompok data yang berhasil dikumpulkan, terpilih 19 kelompok data yang bersumber dari 19 pemustaka sebagai informan. Berikut hasil analisis terhadap data yang diperoleh dari 19 pemustaka tersebut.

\section{Potensi Daya Tarik Wisata Grhatama Pustaka sebagai Wahana Rekreasi}

Ketika akan masuk ke Grhatama Pustaka, seorang pemustaka diwajibkan mengisi "buku tamu" di komputer. Salah satu yang harus diisikan di "buku tamu" ini adalah apa tujuan utama berkunjung ke Grhatama Pustaka. Jawaban atas pertanyaan ini sudah disediakan di komputer dan pemustaka cukup pilih satu dari sejumlah jawaban yang disediakan, yaitu kunjungan biasa/membaca, penelitian, refreshing, tugas kuliah, mencari 
literatur, dan lainnya. Untuk memastikan bahwa pemustaka mengisi "buku tamu" di komputer tersebut, ada petugas keamanan di dekat pintu masuk yang memantau pemustaka yang akan keluar-masuk Grhatama Pustaka.

Pertanyaan tentang tujuan utama berkunjung ke Grhatama Pustaka juga menjadi salah satu pertanyaan yang diajukan oleh tim peneliti kepada pemustaka. Ketika hal ini ditanyakan kepada informan yang berjumlah 118 pemustaka, sebanyak 54 pemustaka $(45,8$ persen) menjawab kunjungan biasa/membaca, tiga pemustaka $(2,5$ persen $)$ menjawab melakukan penelitian, 17 pemustaka (14,4 persen) menjawab refreshing, 27 pemustaka (22,9 persen) menjawab [mengerjakan] tugas kuliah, sembilan pemustaka (7,6 persen) menjawab mencari literatur, dan delapan pemustaka (6,8 persen) menjawab lainnya. Ketika ditanya lebih lanjut tentang "tujuan lainnya", ada yang menjawab belajar, belajar mandiri, belajar untuk persiapan kuliah, membuat/mengerjakan tugas, dan menemani anak membaca.

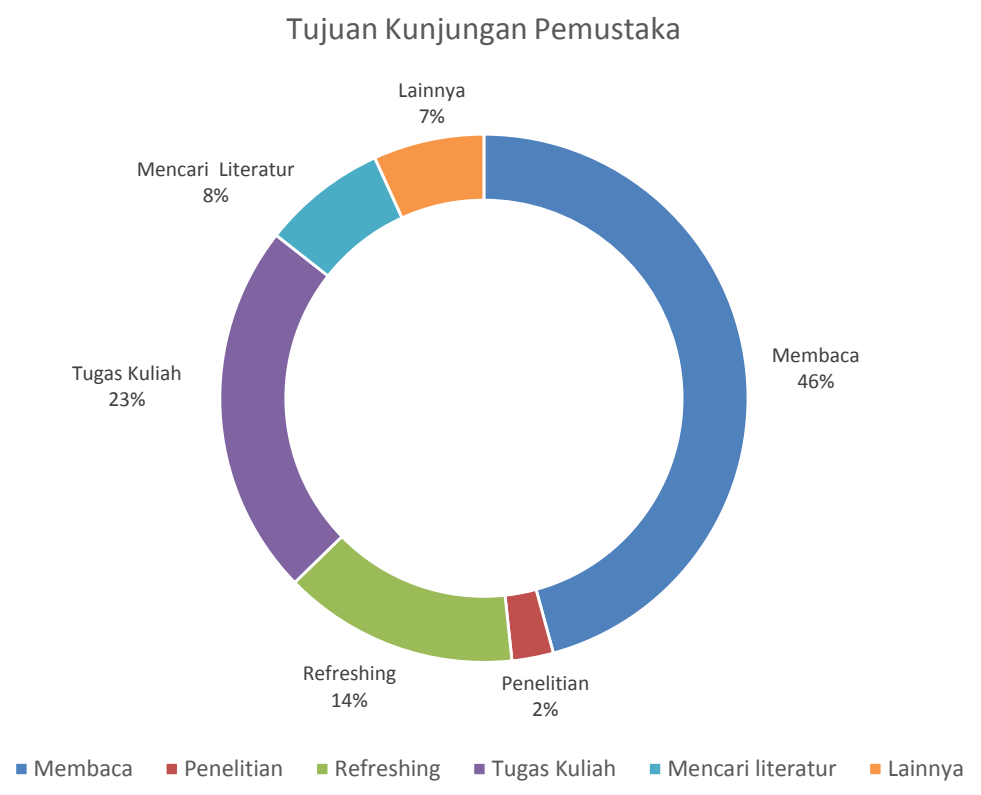

Gambar 1 Tujuan Kunjungan Pemustaka

Ketika ditanya dengan siapa pemustaka berkunjung ke Grhatama Pustaka, kelompok pemustaka yang mengaku berkunjung sendiri ada 43 pemustaka (36,4 persen) yang umumnya bertujuan mencari literatur, mengerjakan tugas sekolah atau kuliah, dan sekadar ingin membaca. Kelompok pemustaka yang berkunjung bersama teman kuliah, teman sekolah, atau teman bermain ada 56 pemustaka (47,5 persen) dengan tujuan 
selain mencari literatur, mengerjakan tugas sekolah atau kuliah, dan sekadar ingin membaca, mereka juga menjadikan kunjungan ke Grhata Pustaka sebagai sarana refreshing. Bahkan ada pemustaka yang sekadar ingin mencari jaringan wi-fi agar bisa mengakses internet gratis untuk berselancar di dunia maya atau sekadar bermain game. Kelompok yang berkunjung bersama keluarga ada 19 pemustaka (16,1 persen) yang umumnya bertujuan untuk refreshing. Hal ini menunjukkan bahwa tujuan pemustaka yang berkunjung ke Grhatama Pustaka jika dikaitkan dengan fungsi perpustakaan bisa dikelompokkan menjadi dua kategori. Pertama, pemustaka yang berkunjung untuk tujuan refreshing umumnya datang secara berkelompok, baik bersama teman kuliah, teman sekolah, teman bermain, maupun bersama keluarga. Kedua, pumustaka yang berkunjung untuk tujuan selain refreshing baik untuk mencari literatur, mengerjakan tugas sekolah atau kuliah, maupun sekadar ingin membaca umumnya datang sendiri (secara individu).

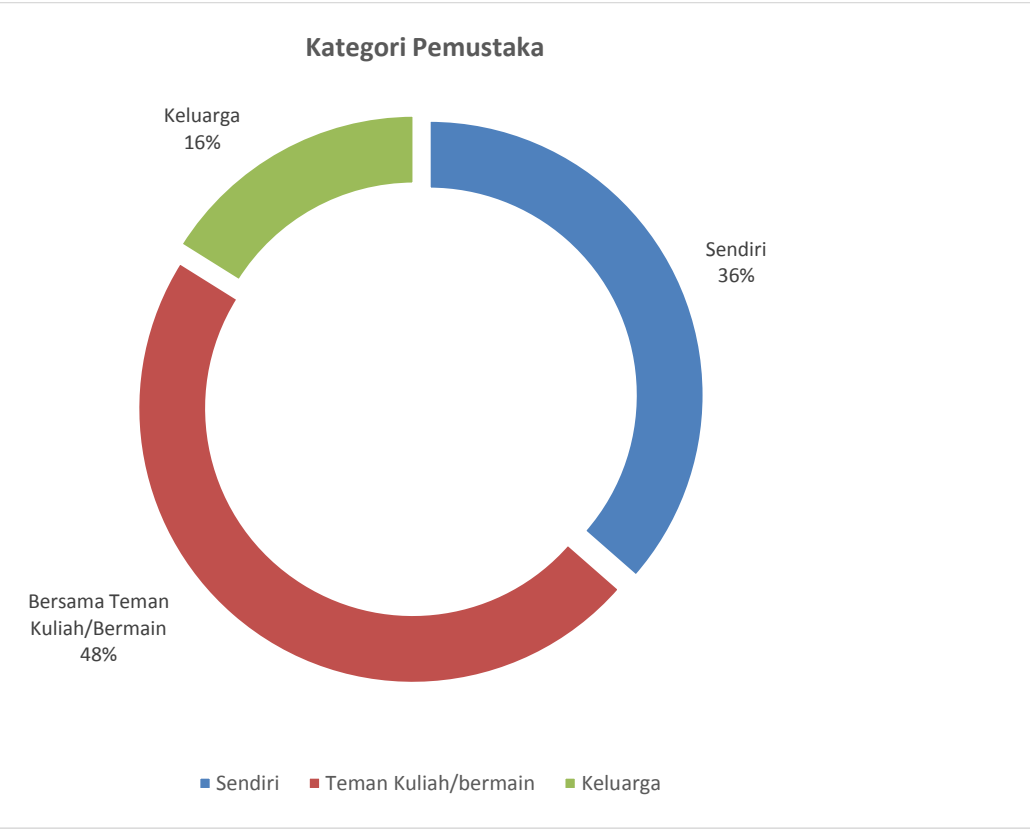

Gambar 2 Kategori Pemustaka

Priyono (37 tahun), pekerja swasta asal Purwokerto, adalah salah satu pengunjung yang datang bersama keluarga. Ketika diwawancarai, Priyono mengatakan bahwa tujuan dia bersama keluarga berkunjung ke Grhatama Pustaka adalah untuk refreshing. Tempat yang mereka kunjungi adalah Ruang Koleksi Buku Anak (Lantai 1) karena anak Priyono suka membaca. Selain itu, mereka juga mengunjungi Ruang Musik Anak dan Ruang Bioskop 6 Dimensi (keduanya juga di Lantai 1). Ketika ditanya mengapa untuk 
refreshing memilih Grhatama Pustaka, Priyono menjawab bahwa sulit mendapatkan tempat seperti Grhatama Pustaka yang bisa dijadikan sebagai tempat kumpul keluarga sambil membaca. Dari hasil wawancara ini diketahui bahwa bagi Priyono dan keluarga, kegiatan kumpul bersama keluarga sambil membaca merupakan salah satu bentuk refreshing yang tidak bisa dilakukan di sebarang tempat. Priyono sekeluarga memutuskan memilih Grhatama Pustaka karena menurut Priyono, Grhatama Pustaka adalah salah satu tempat yang bisa memenuhi keinginan mereka, yaitu kumpul keluarga sambil membaca. Karena termasuk tempat yang "sulit didapatkan", Grhatama Pustaka memenuhi kriteria keunikan sehingga berpotensi menjadi sebuah daya tarik wisata.

Pemustaka yang juga tertarik berkunjung ke Lantai 1 Grhatama Pustaka adalah Purwaningsih (27). Lulusan SMA yang tinggal di Yogyakarta dan bekerja sebagai pegawai swasta ini biasanya berkunjung ke Grhatama Pustaka bersama keluarga. Ketika ditanya apa tujuan berkunjung ke Grhatama Pustaka, Purwaningsih menjawab refreshing. Bagian yang menurutnya menarik adalah di Ruang Bioskop 6 Dimensi (Lantai 1) dan Ruang Musik Anak (Lantai 1).

"[Saya] Mengantar anak untuk membaca dan menonton film petualangan. Kalau di Ruang Musik karena ruang musiknya lengkap dan anak saya suka main drum dan piano." (Wawancara dengan Purwaningsih, 24 Juni 2019)

Sebagaimana Purwaningsih, seorang pegawai swasta bernama Gugut (37) sering berkunjung ke Grhatama Pustaka bersama keluarga. Gugut biasa berkunjung ke Grhatama pada Minggu siang setelah pukul pukul 12.00. Bagian yang menarik dan sering dikunjungi oleh Gugut sekeluarga untuk refreshing antara lain adalah Ruang Koleksi Buku Anak dan Ruang Musik Anak yang keduanya berada di Lantai 1 Gedung Grhatama Pustaka.

Tidak hanya pemustaka keluarga yang tertarik berkunjung ke Lantai 1. Seorang mahasiswi juga ada yang tertarik berkunjung ke Lantai 1 . Fransisca (20) adalah salah satunya. Fransisca biasa berkunjung ke Grhatama Pustaka pada hari Sabtu siang setelah pukul 12.00. Dia sering datang sendiri sekadar untuk refreshing dan mengaku tertarik di bagian anak-anak (Lantai 1). Ketika ditanya mengapa memilih Grhatama Pustaka untuk refreshing, perempuan asal Bandung ini menjawab,

"[Grhatama Pustaka adalah] Tempat yang asyik tanpa harus membaca buku berat". (Wawancara dengan Fransisca, 29 Juni 2019) 
Baik keluarga Priyono, keluarga Purwaningsih, keluarga Gugut, maupun Fransisca berkunjung ke Grhatama Pustaka dengan tujuan utama untuk refreshing. Bagian dari Grhatama Pustaka yang menarik bagi mereka adalah Lantai 1, khususnya Ruang Koleksi Buku Anak, Ruang Musik Anak, dan Ruang Bioskop 6 Dimensi. Bagian-bagian ruangan dengan kenyamanan yang ditawarkan menurut mereka termasuk tempat yang jarang atau "sulit ditemukan" di perpustakaan lain yang ada di Yogyakarta sehingga memenuhi kriteria keunikan dan berpotensi menjadi sebuah daya tarik wisata.

Selain Lantai 1, area terbuka yang berada di tengah-tengah Gedung Grhatama Pustaka dan taman yang dilengkapi gazebo adalah bagian dari Grhatama Pustaka yang menurut pemustaka menarik untuk dikunjungi. Nugroho (28), seorang wiraswasta yang tinggal di Bantul biasa berkunjung ke Grhatama Pustaka bersama keluarga untuk refreshing. Bagian yang sering dikunjungi keluarga ini adalah area terbuka di tengah gedung dan gazebo luar. Menurut Nugroho, mereka tertarik dan sering berkunjung ke area terbuka di tengah gedung dan gazebo luar karena tempatnya luas, ada mainan anak, dan bisa bermain di rumput.

Rahmah (20), mahasiswi asal Yogyakarta juga tertatik dan sering mengunjungi taman yang ada di Grhatama Pustaka dan Ruang Koleksi Umum yang berada di Lantai 2 untuk refreshing. Ketika ditanya mengapa memilih dua lokasi itu, Rahmah mengatakan bahwa taman yang ada di Grhatama Pustaka merupakan tempat yang menarik untuk memanjakan mata, sementara Ruang Koleksi Umum merupakan ruang yang bisa memuaskan keinginannya untuk membaca.

"[Di Ruang Koleksi Umum] bisa membaca buku sepuasnya, sesuatu yang tidak bisa dilakukan pada hari-hari biasa." (Wawancara dengan Rahmah, 30 Juni 2019)

Selain Rahmah, mahasiswi lain yang tertarik dan sering datang ke taman yang ada di Grhatama Pustaka dan Ruang Koleksi Umum untuk refreshing adalah Choirunnisa (20). Alasan Choirunnisa tertarik berkunjung ke taman di Grhatama Pustaka karena menurut dia tempatnya sejuk, nyaman, juga tenang. Sementara Ruang Koleksi Umum di Lantai 2 dia pilih karena dia bisa membaca dan menulis dengan nyaman karena sepi.

Setiadi (29), seorang desainer grafis lepas, yang tinggal di Yogyakarta, juga sering berkunjung ke Grhatama Pustaka untuk refreshing. Ruang Koleksi Umum dan gazebo taman di Grhatama Pustaka dia pilih untuk aktivitas membaca buku. Dia biasa berkunjung pada hari Sabtu pagi, sekitar pukul 08.00--12.00. 
Beberapa pemustaka lain yang tujuan utamanya berkunjung ke Grhatama Pustaka untuk refreshing sekaligus menyatakan bahwa Ruang Koleksi Umum yang berada di Lantai 2 adalah tempat yang menarik untuk dikunjungi antara lain Faris, Kevin, Yulianto, dan Putri. Faris (16) pelajar SMA yang tinggal di Yogyakarta, menyatakan mengunjungi Ruang Koleksi Umum karena ruangannya sejuk sehingga nyaman untuk membaca dan mengerjakan tugas sekolah. Kevin (20), seorang mahasiswa, menyatakan mengunjungi Ruang Koleksi Umum untuk meminjam buku, mengembalikan buku, dan membaca buku kemudian dilanjut duduk berlama-lama di Ruang Tunggu Grhatama Pustaka untuk browsing karena ada Wi-Fi gratis. Yulianto (21), seorang pemuda lulusan SMA yang bekerja sebagai penjaga gerai ponsel, menyatakan selain Ruang Koleksi Majalah dan Koran di Lantai 3, dia sering berkunjung ke Ruang Koleksi Umum pada malam hari (pukul 18.00 sampai tutup Grhatama Pustaka) karena tertarik dengan koleksi buku agama yang cukup banyak dan dia merasa rugi jika belum membaca bukubuku agama tersebut. Putri (22), seorang mahasiswi yang biasa berkunjung ke Grhatama Pustaka bersama teman pada hari Selasa, Rabu, dan Kamis siang pukul 12.00--17.00, selain sering berkunjung ke Ruang Koleksi Skripsi di Lantai 3 Grhatama Pustaka untuk mencari bahan bacaan dan referensi untuk skripsi, dia suka berkunjung ke Ruang Koleksi Umum karena tempatnya nyaman dan fasilitasnya lengkap.

Area terbuka yang ada di tengah gedung Grhatama Pustaka, gazebo di taman yang ada di Grhatama Pustaka, Ruang Koleksi Umum yang berada di Lantai 2, Ruang Koleksi Majalah dan Koran di Lantai 3, dan Ruang Koleksi Skripsi di Lantai 3 adalah lokasi yang menurut beberapa pemustaka menarik untuk dikunjungi dengan berbagai argumen sebagaimana sudah disebutkan di atas. Berdasarkan interpretasi terhadap hasil wawancara dengan beberapa pemustaka, selain memenuhi kriteria keunikan (karena jarang atau sulit ditemukan di perpustakaan lain) lokasi-lokasi tersebut juga memenuhi kriteria indah (karena dapat menimbulkan perasaan senang sehingga timbul rasa puas). Dengan demikian, kelima lokasi tersebut berpotensi menjadi sebuah daya tarik wisata.

Bagian lain dari Grhatama Pustaka yang menurut pemustaka menarik adalah Ruang Koleksi Langka di Lantai 3, Ruang Koleksi Pustaka Nusantara di Lantai 3, serta Ruang Koleksi Budaya (jadi satu dengan Ruang Koleksi Majalah dan Koran di Lantai 3). Beberapa pemustaka yang tujuan utamanya berkunjung ke Grhatama Pustaka untuk refreshing sekaligus menyatakan bahwa ruang-ruang tersebut adalah tempat yang menarik untuk dikunjungi antara lain Iksan, Hidayat, Billy, Meytha, dan Mufid. Iksan (26), mahasiswa pascasarjana yang tinggal di Yogyakarta sering berkunjung ke Ruang Koleksi Langka untuk membaca buku sekaligus refreshing. Hal yang lebih 
kurang sama dilakukan Hidayat (31), seorang PNS/ASN yang biasa berkunjung ke Ruang Koleksi Langka dan Ruang Koleksi Majalah dan Koran karena merasa bahwa tempat tersebut nyaman untuk membaca. Billy (13), pelajar SMP yang pada Sabtu siang setelah pukul 12.00 sering berkunjung ke Grhatama Pustaka bersama keluarga menyatakan selain mengunjungi taman/gazebo yang nyaman dan sejuk, dia juga sering masuk "Ruang Budaya" (Ruang Koleksi Pustaka Nusantara) karena relatif sepi sehingga dia bisa leluasa menikmati jaringan Wi-Fi gratis. Pelajar yang lain, Mufid (14), biasa berkunjung ke Grhatama Pustaka pada Minggu pagi (pukul 08.00--12.00) untuk mencari buku sejarah di "Ruang Budaya" (Ruang Koleksi Majalah, Koran, dan Budaya Timur serta Ruang Koleksi Pustaka Nusantara. Sementara Meytha (23), seorang guru yang tinggal di Sleman, sering berkunjung ke Grhatama Pustaka pada Sabtu siang setelah pukul 12.00 untuk membaca di Ruang Koleksi Umum dan Ruang Koleksi Pustaka Nusantara.

Selain Ruang Koleksi Majalah, Koran, dan Budaya Timur serta Ruang Koleksi Skripsi, ruang-ruang yang ada di Lantai 3 Grhatama Pustaka yang menurut beberapa pemustaka menarik untuk dikunjungi sebagaimana dipaparkan di atas adalah Ruang Koleksi Langka dan Ruang Koleksi Pustaka Nusantara. Berdasarkan interpretasi terhadap hasil wawancara dengan beberapa pemustaka, selain memenuhi kriteria keunikan (karena jarang atau sulit ditemukan di perpustakaan lain) lokasi-lokasi tersebut juga memenuhi kriteria indah (karena dapat menimbulkan perasaan senang sehingga timbul rasa puas). Dengan demikian, lokasi-lokasi tersebut juga berpotensi menjadi sebuah daya tarik wisata.

Paparan di atas menunjukkan bahwa berdasarkan perspektif pemustaka, Grhatama Pustaka Yogyakarta menarik untuk dikunjungi sehingga berpotensi menjadi daya tarik wisata. Lokasi potensi daya tarik wisata Grhatama Pustaka sebagai wahana rekreasi berdasarkan perspektif pemustaka sekilas kriterianya dapat dilihat pada tabel 1.

Tabel 1. Potensi Daya Tarik Wisata Grhatama Pustaka sebagai Wahana Rekreasi

\begin{tabular}{llll}
\hline No & Lokasi & \multicolumn{1}{c}{ Potensi } & \multicolumn{1}{c}{$\begin{array}{c}\text { Kriteria yang } \\
\text { Terpenuhi }\end{array}$} \\
\hline 1 & Luar & $\begin{array}{l}\text { a. Area terbuka di tengah gedung } \\
\text { b. Gazebo/taman luar }\end{array}$ & $\begin{array}{l}\text { Keunikan dan } \\
\text { Keindahan }\end{array}$ \\
\hline
\end{tabular}




\begin{tabular}{|c|c|c|c|}
\hline 2 & Lantai 1 & $\begin{array}{l}\text { a. Ruang Koleksi Buku Anak } \\
\text { b. Ruang Musik Anak } \\
\text { c. Ruang Bioskop } 6 \text { Dimensi }\end{array}$ & Keunikan \\
\hline 3 & Lantai 2 & $\begin{array}{l}\text { a. Ruang Koleksi Umum } \\
\text { b. Ruang Koleksi Braille }\end{array}$ & Keunikan \\
\hline 4 & Lantai 3 & $\begin{array}{l}\text { a. Ruang Koleksi Majalah, } \\
\text { Koran, dan Budaya Timur } \\
\text { b. Ruang Koleksi Skripsi } \\
\text { c. Ruang Koleksi Langka } \\
\text { d. Ruang Koleksi Pustaka } \\
\text { Nusantara }\end{array}$ & Keunikan \\
\hline
\end{tabular}

Sumber: Hasil Olah Data, 2019

Beberapa lokasi di Grhatama Pustaka Yogyakarta memang berpotensi untuk dikembangkan sebagai daya tarik wisata. Meskipun demikian, berdasarkan catatan hasil pengamatan di Grhatama Pustaka Yogyakarta dan hasil wawancara terhadap pemustaka di luar pemustaka yang tujuan utamanya berkunjung ke Grhatama Pustaka untuk refreshing, ada dua hal yang menjadi catatan.

Pertama, kenyamanan merupakan salah satu yang dicari pemustaka sehingga mereka tertarik untuk berkunjung ke Grhatama Pustaka. Nuraini (18), seorang pelajar asal Bantul yang berkunjung ke Grhatama Pustaka untuk belajar mengaku lebih suka berada di Ruang Koleksi Braille di Lantai 2. Ketika ditanya mengapa memilih ruang tersebut, Nuraini menjawab bahwa Ruang Braille cukup sepi dan tenang sehingga nyaman untuk belajar. Ruang Braille adalah ruangan yang diperuntukkan bagi para penyandang tunanetra. Ketika tim peneliti melakukan observasi di ruang ini pada Senin, 24 Juni 2019 pukul 10.20, hanya ada tiga orang pemustaka. Alasan mereka pun tidak untuk membaca buku braille (karena mereka bukan penyandang tunanetra), melainkan untuk belajar atau keperluan lain seperti yang dilakukan Nuraini.

Kedua, jam operasional Grhatama Pustaka yang sampai malam adalah salah satu hal lain yang dicari oleh pemustaka sehingga mereka tertarik untuk berkunjung ke Grhatama Pustaka. Ardiansyah (19), seorang mahasiswa, ketika ditanya mengapa tertarik berkunjung ke Grhatama Pustaka dan ruang/area mana yang sering dikunjungi, dia menjawab, "Ruang koleksi umum karena koleksinya lengkap. Selain itu, cuman perpustakaan ini yang buka hingga jam sepuluh malam.” Jam operasional Grhatama Pustaka 
yang sampai malam merupakan salah satu alasan yang membuat pemustaka tertarik untuk berkunjung. Namun, pada hari Sabtu dan Minggu ketika banyak pemustaka punya waktu luang untuk berkunjung ke Grhatama Pustaka Yogyakarta, justru jam operasional Grhatama Pustaka Yogyakarta tidak sampai malam, melainkan hanya sampai pukul 16.00.

Kedua catatan di atas perlu mendapat perhatian karena kembali menguatkan kriteria "keunikan" yang dimiliki Grhatama Pustaka sehingga berpotensi menjadi sebuah daya tarik wisata. Faktor "kenyamanan" dan "jam operasional sampai malam" menjadi kekuatan penarik bagi pemustaka untuk berkunjung, meskipun tujuan utama mereka bukan untuk refreshing.

\section{KESIMPULAN}

Simpulan penelitian ini adalah berdasarkan perspektif pemustaka, Grhatama Pustaka Yogyakarta menarik untuk dikunjungi sehingga berpotensi menjadi daya tarik wisata, lebih spesifik lagi untuk refreshing keluarga. Meskipun demikian, saat ini fungsi Grhatama Pustaka Yogyakarta sebagai wahana rekreasi belum maksimal. Berdasarkan simpulan ini, peneliti menyarankan dua hal. Pertama, secara teoretis perlu kajian lebih lanjut khususnya tentang pengembangan Grhatama Pustaka Yogyakarta sebagai wahana rekreasi. Kedua, secara praktis jam operasional pada hari Sabtu dan Minggu harus ditambah karena menurut pemustaka pada akhir pekan inilah mereka punya banyak waktu luang untuk berkunjung ke Grhatama Pustaka Yogyakarta tetapi yang disayangkan adalah justru pada akhir pekan (Sabtu dan Minggu) jam operasional Grhatama Pustaka Yogyakarta hanya sampai pukul 16.00. Dengan menambah jam operasional pada akhir pekan diharapkan fungsi Grhatama Pustaka Yogyakarta sebagai wahana rekreasi bisa lebih maksimal.

\section{DAFTAR RUJUKAN}

Aisyah, S. (2017). Implementasi kebijakan aksesibilitas pelayanan bagi difabel di Yogyakarta tahun 2015 : Studi kasus Grhatama Pustaka Yogyakarta. Yogyakarta: Program Studi Ilmu Pemerintahan Fakultas Ilmu Sosial dan Politik Universitas Muhammadiyah.

Bahasa, T. P. (2016). Kamus besar bahasa Indonesia edisi kelima. Jakarta: Kementerian Pendidikan dan Kebudayaan Republik Indonesia.

Creswell, J. (2012). Research design: Pendekatan kualitatif, kuantitatif, dan mixed. Yogyakarta: Pustaka Pelajar. 
Mamik. (2015). Metodologi Kualitatif. Sidoarjo: Zifatama Publisher.

Mianto. (2014). Persepsi pemustaka terhadap kualitas pelayanan sirkulasi di Badan Perpustakaan dan Arsip Daerah Daerah Istimewa Yogyakarta. Yogyakarta: Program Studi Ilmu Perpustakaan, Fakultas Adab dan Ilmu Budaya Universitas Islam Negeri Sunan.

Musrifah. (2016). Proteksi arsip vital pada Badan Perpustakaan dan Arsip Daerah di Yogyakarta. Jurnal Kajian Informasi \& Perpustakaan, 135--148.

Puspitasari, D. (2015). Peranan Badan Perpustakaan dan Arsip Daerah Provinsi Daerah Istimewa Yogyakarta dalam pengelolaan arsip daerah guna meningkatkan pelayanan arsip terhadap publik. Yogyakarta: Universitas Gadjah Mada.

Romrome, M. (2015). Kompasiana. Retrieved Jun 3, 2020, from Filosofi Perspektif:

https://www.kompasiana.com/marselmsc/54ff5e8ca33311be4c50fd95 /filosofi-perspektif

Rukajat, A. (2018). Pendekatan penelitian kuantitatif (Quantitative research approach). Yogyakarta: Deepublish.

Sekarini, L. (2016). kebanggaan baru Yogyakarta. Retrieved Juni 3, 2020, from Grhatama Pustaka: http://wargajogja.net/sosial/grhatamapustaka-kebanggaan-baru-yogyakarta.html.

Sugiarto. (2016). Pengantar Ekowisata. : . Yogyakarta: Khitah Publishing.

Sugiyono. (2013). Memahami Penelitian Kualitatif. Bandung: Alfabeta.

Sekarini, L.A. (2016). Grhatama Pustaka, kebanggaan baru Yogyakarta. Diakses 3 Juni, 2020, dari http://wargajogja.net/sosial/grhatamapustaka-kebanggaan-baru-yogyakarta.html.

Sekretariat Negara RI. (2007). Salinan Lembaran Negara Republik Indonesia Tahun 2007 Nomor 129: Undang-Undang Republik Indonesia Nomor 43 Tahun 2007 tentang Perpustakaan. Jakarta: Biro 
142 | TIK ILMEU: Jurnal IImu Perpustakaan dan Informasi, vol. 4, no. 2, 2020

Peraturan Perundang-undangan Bidang Politik dan Kesejahteraan Rakyat. 